\title{
Contrasting Monetary and non-monetary measures of poverty in developing countries: a survey
}

Hicham El Azami ( $D$ B00395129@essec.edu )

Peking University

\section{Systematic Review}

Keywords: poverty, monetary, non-monetary, mismatch, multidimensional, income, consumption, MPI

Posted Date: May 21st, 2021

DOI: https://doi.org/10.21203/rs.3.rs-537501/v1

License: (a) (i) This work is licensed under a Creative Commons Attribution 4.0 International License. Read Full License 


\title{
Contrasting Monetary and non-monetary measures of poverty in developing countries: a survey
}

\author{
Hicham El Azami, Peking University
}

\begin{abstract}
While the study of poverty is popular amongst academia, there is yet to be a consensus on what defines such a phenomenon. Basing their arguments on different conceptual frameworks, some argue for a definition in monetary terms, as a lack of income or consumption, while others support a non-monetary approach focusing on shortcomings in diverse dimensions (health, education, nutrition...). Does it really matter that researchers do not agree on a definition of a poverty? Probing the empirical literature comparing monetary and non-monetary poverty in developing countries, this survey argues that different definitions of poverty lead to different populations identified as poor. Indeed, cross-tabulating poverty headcounts, it finds that a sizable portion of the non-monetary poor are excluded by the monetary approach. Moving to a subgroup level, it finds nonmonetary poverty amongst the monetary richest, and considerable disagreements with regards to poverty risks. In addition, these significant differences are not resolved when switching to a dynamic setting through panel studies. Policy implications are important: the risk mistargeting and misevaluation of policies is high if we do not consider both approaches concomitantly without one taking precedence over the other.
\end{abstract}




\section{I- Introduction}

According to the World Bank and based on a 1.90\$/day poverty line, 689 million people were living in extreme monetary poverty in 2017 (World Bank, 2021). The same year, 132 million more people were identified as undernourished (UN, 2019), while 832 million more people lived in fragile settings with weak national capacities to deliver basic health services (UN, 2019). Besides, 2.3 billion people still lacked access to basic sanitation (UN, 2019), which is nearly the triple of monetary poverty headcount.

Thus, it appears clear that the elimination of extreme monetary poverty (Sustainable Development Goal 1.1) would not necessarily lead to the eradication of hunger and exclusion from health and sanitation services. But these other forms of deprivation are also part of Sustainable Development Goals (in fact SDG 1.2 declares an objective of ending poverty "in all its forms"), and few would argue that they do not constitute attributes of poverty. This begs the question of how efficient the monetary metric is in tracking the real progress of poverty alleviation. It also points to the complexity of defining poverty.

Indeed, as Ruggeri Laderchi (2003) posits, there are many competing conceptual frameworks to define poverty, amongst which the capability approach, the utilitarian approach, and the participatory approach. These all offer different normative definitions of poverty that lead to differences in the identified poverty headcounts and severity. Besides the underlying concepts, there exists also disagreements concerning the operationalization of a poverty study: what cutoff should be applied to segregate the 
poor? Should we aggregate measures of poverty in indexes or present them in dashboards?

However, there seems to be a consensus amongst researchers on the multidimensionality of poverty (Ravaillon, 2011; Alkire and Foster, 2011b; Atkinson, 2019). This consensus has slowly emerged since the 1960' when Seers (1969) published its article "The meaning of development", which expanded the measurement of poverty beyond GDP. It stems mainly from the inherent complexity of this phenomenon (Scheidel, 2012): it cannot be reduced to a single definition, but multiple non-equivalent legitimate meanings co-exist. It also points to the incommensurability of poverty measures (Martinez Allier, 1998; Scheidel, 2012), which may be difficult to represent on the same scale: What would be for example a common measure capturing low levels of income and high rates of child mortality? Would someone be better off with more child mortality but a higher income? These non-trade off cases suggest that poverty may not be considered in a unidimensional manner.

Even linguistics seems to give rise to the multidimensional nature of poverty. As showed by Wang (2016), the Chinese definition of poverty: 贫困 would translate as “little wealth". But “wealth" here should not be restricted to monetary means alone. Indeed, Xinhua dictionary tells us that 贫 points to “little income and difficulties in life", while 困 means "falling into a harsh environment, or an environment that one cannot shake off". It can be thus inferred that poverty is not a lack of income only but also signals the presence of "harsh environments", or dimensions. 
Nonetheless, unidimensional measures of poverty, and especially monetary ones, are to this day considered the gold standard of poverty measurement and taken the center stage of development policies (Sumner, 2007). This preferential treatment is illustrated by the different international objectives fixed to alleviate poverty, amongst which the Millennium Development Goals. These 8 development goals adopted by 191 countries in 2000 consecrated the center-stage position of monetary measures of poverty: eliminating poverty measured as a money metric (living on less than $1.25 \$$ a day) represents the first goal to be achieved while improving basic education for children and alleviating child mortality comes second and fourth respectively (UN, 2008). Despite the significant advance in measuring multidimensional poverty with the introduction of the Multidimensional poverty index (Alkire, 2015), monetary measures continue to hold a position of "first among equals" in the new Sustainable Development Goals, adopted by the UN general Assembly in 2015: Eliminating extreme poverty defined by a $1.90 \$ /$ day poverty line is Goal 1.1, while "Good Health and well-being" is Goal3 and "Quality Education" is Goal 4 (UN, 2019). As a testament to the new rise of multidimensional measures of poverty, Sustainable Goal 1.2 does refer to an objective of halving the "proportion of men, women and children of all ages living in poverty in all its dimensions". However, this is not supplemented with a clear definition of what these dimensions are, nor a proper international cutoff. Indeed, it sends back to "national definitions" of multidimensional poverty.

Going from international to national settings, the predominance of monetary measures over non-monetary ones still holds. This can be seen in poverty reduction strategy papers (PRSP) which are prepared by low-income countries together with international 
development partners to present their poverty alleviation roadmap and apply for debt relief and aid: these usually use a consumption-based poverty line as the only indicator of progress (Geske, 2011).

An important proponent of the "monetization" of the concept of poverty has been the World Bank (Konkel, 2014). While poverty was discarded as secondary compared to economic growth (in line with Kuznets Growth theory), it has taken the center stage of the World Bank agenda since the 1970's. World Bank economists have tried to put a universal quantitative yardstick on a complex phenomenon and came with the dollar-aday approach in 1990. It was a pragmatic way to evaluate projects, but did it the reflect the reality of poverty?

Indeed, if monetary and non-monetary multidimensional measures identified the same population as poor, there would not be any issue with using income or consumption exclusively. However, empirical literature has identified a significant mismatch in identifying the poor (Alkire, 2015): focusing on monetary measures might disregard important poverty dynamics and lead to mistargeting.

The empirical investigation of this mismatch has taken many routes. Some have compared the two measures on a macro-level, pointing that positive income trends do not necessarily lead to improvements in non-monetary dimensions (Bourguinon et al (2010); Alkire et. al (2014)). Other have focused on cross-country comparisons: Dreze and Sen (2013), compared India and Bangladesh development trajectories between 1990 and 2011 and found that while India exhibited a higher progression on GDP per capita, Bangladesh far outperformed it on child mortality, immunization, and female literacy. 
Another trend in empirical literature has been to compare monetary and non-monetary measures of poverty from the same dataset. This has been allowed by the growing amount of non-monetary indicators captured in the national household surveys (Alkire, 2018). In a survey of high-income countries, Perry (2002) has found that monetary and non-monetary measures only present a modest overlap in identifying poor. For example, amongst the population identified as poor by an income poverty line in New Zealand, only $40 \%$ would also be identified as poor by a non-monetary measure of poverty: $60 \%$ of non-monetary poor would not be targeted by poverty alleviation policies (which are based on income measures). Boarini (2006) has found comparable results in a survey of the mismatch in OECD countries. However, it is to be noted that these findings stem from high income countries, with specific definitions of deprivation and with a relative definition of poverty (usually $60 \%$ of median income).

Some have argued that the mismatch might be due to considering the two measures in a static setting, and thus contrasted monetary and non-monetary indicators in a dynamic setting using panel data (Bradshaw and Finch, 2003, Whelan, 2004, Tran, 2015). Indeed, it can be argued that static comparisons are only a snapshot of poverty and do not disregard the variety of poverty status with time as a variable. However, these empirical investigations have all found that the considerable mismatch, while lowered for some (Whelan, 2004), is still present in a dynamic setting.

To solve this issue, some have argued for using both measures (Bradshaw and Finch, 2003; Bag and Seth, 2018) while other have tried to combine both in an index, with mixed results for policy information (Evans, 2020). 
This survey attempts to gather evidence on this empirical effort. As opposed to Boarini (2006) and Perry (2002), it will mainly focus on low to median income countries. These countries have traditionally relied on absolute definitions of poverty (with a poverty line based on basic caloric needs) and thus may present different insights on the mismatch. In addition, this survey includes empirical work that has used a new non-monetary measure of poverty: the multidimensional poverty index. This aggregate introduced by Alkire (2011) has been gaining traction in the field of poverty alleviation, with multiple developing countries adopting it as an official poverty measurement with support from Oxford Poverty and Human Development Initiative (OPHI) (see Alkire, 2015). In a research agenda outlined by OPHI in 2018 (Alkire, 2018), the mismatch between monetary and non-monetary multidimensional poverty is designed as an under researched area for developing countries, while the same phenomenon has received considerable attention in developed countries. This review addresses this gap in the literature.

Based on key findings from said literature, we argue that monetary and non-monetary measures of poverty are inherently different and present a different perspective on poverty and as such, they should be both used as an aid to policy making.

This first part will introduce the topic, while the second part will delve into the conceptual frameworks guiding monetary and non-monetary measures of poverty. The third part will focus on presenting the empirical literature selected and the review process studying while the fourth part will introduce key findings from this corpus. Finally, the fifth part will discuss policy implications of said findings, the reviews' limitations and conclude. 


\section{II- Conceptual Framework}

Poverty measurements do not take place in a vacuum (Suppa, 2016): they are entrenched in conceptual frameworks that tell poverty narratives which explain what exactly should be measured and why (Gamboa, 2020). Given that poverty analysis is a popular field, numerous conceptual frameworks compete and dictate which tool to use: either monetary, non-monetary or a mixture of both.

Each of these frameworks present with advantages and disadvantages. This part will try to assess the ones most invoked in the literature: the monetary approach, the capability approach, and the participatory approach. Contrasting these three frameworks will help shed light on the drivers behind the important mismatch in identifying the poor, which is attested by empirical literature.

\section{The Monetary Approach:}

\section{a. Origin and Definition}

As pointed by Ruggeri Laderchi (2003), the monetary approach has been the dominating conceptual framework for poverty measurement since the start of poverty studies. Indeed, this approach goes as far back as the 19th and early 20th century with the works of Booth and Rowntree who studied poverty in England. Rowntree (1902) is credited with the first scientific study of poverty: he defined a poverty line according to a standard adequate diet then added a needed budget for clothing and rent. What is more, the monetary approach is still used by most national governments and international development agencies in defining their poverty alleviation plans (Sumner, 2007). 
What exactly constitutes a monetary approach? Under this approach umbrella, are held together a multitude of methods which all share the use of a monetary medium (either income or consumption) as the central tenant to the quest of identifying the poor.

Indeed, the first step when determining poverty rates using the monetary approach is setting a poverty line (Haughton and Khandker, 2009). There is no consensus on how to determine such a line, but two main methods have emerged. One is concerned with the cost of acquiring a basket of food deemed necessary. This cost is imputed using human needs in daily calories multiplied by local market prices. The advocates of this method generally add a multiple to this poverty line, to account for non-food items. Indeed, even, the poorest individuals must dedicate some expenditure to non-food items (Banerjee and Duflo, 2007). When cost of food items is not available, some have argued for the food energy intake method (Haughton and Khandker, 2009): expenditure (or income) is regressed against food consumption to determine the expenditure (or income) level at which food needs are satisfied. This level of expenditure (or income) is used as a poverty line.

Once the issue of poverty line is settled, two mediums can lead to identifying the poor: either measuring all sources of income or recording consumption while affixing prices to any non-market goods. These are usually measured at the household level and then translated into per capita indicators through equivalence scales (Haughton and Khandker, 2009) 


\section{b. Advantages}

The main argument for the use of the monetary approach for identifying the poor is its adequacy with micro-economics theory (Ruggeri Laderchi, 2003). Indeed, it satisfies the underlying assumptions of microeconomics by being linked to utility maximization theory: any consumer will maximize its utility (in a homogeneous manner) and consumption (or income) will reflect the value placed on a commodity. This suggests that while monetary measures of poverty are not direct measures of a shortfall in welfare, they are reliable proxies: monetary means will eventually be converted to outcomes or direct measures of poverty. If we take the example of a poor person who suddenly sees its income rising, it is expected that its access to health services will also improve.

Another argument for the use of the monetary approach holds that monetary instruments may be direct measures of poverty. Indeed, Atkinson (1989) argues for a universal basic income as a minimum right. Like basic education, a basic income would in itself constitute a vector of welfare.

Besides these core arguments, technical reasons may also explain the dominance of the monetary approach. Indeed, Sumner (2007) points that development agencies and governments aim for easy-to gather and cost-effective poverty measures. Assembling monetary indicators may seem less costly and more straightforward. Besides monetary indicators are perceived as more "rigorous". This goes to a general finding in development studies research, where quantitative measures are favored (White, 2002). 


\section{c. Disadvantages}

Arguments for the monetary approach are based on assumptions that may not hold true in real life.

First, it posits that individuals are rational and driven by utility maximization (Johannsen et. al 2007). However, Mullainathan and Shafir (2013) show that scarcity can change individual's behavior turning them into irrational agents. They find that poverty "reduces a person's cognitive capacity more than going one full night without sleep" (Mullainathan and Shafir 2013,p. 13). In addition, Banerjee and Duflo (2011) found that some income poor people prefer to buy a television or a cellphone rather than food or cheap immunization for their children: few would argue that this constitutes a rational behavior.

Second, it assumes that individuals' preferences are homogeneous (Thorbecke, 2007) But can we really attest that individuals' utility functions are essentially the same? What about socio-demographic and cultural variations?

Third, it posits that utility only streams from market goods (Thorbecke, 2007), thus ignoring any positive or negative externalities streaming from non-market goods. This is particularly problematic in countries with important social welfare programs: how to account for free education and health?

Fourth, it does not account well for the chronicity of poverty. Spicker (2007) explains that chronicity is important because transitory poverty does not account for total poverty. Given that Income and Consumption are more volatile compared to non-monetary measures, they might not be a good proxy for identifying the chronic poor. This is in line 
with Clark and Hulme (2005) argument that flows, such as income, are more time variant than stocks, such as housing conditions or educational attainment. It is based on a flowfund theoretical framework developed by Georgescu-Roegen (1971) elaborated to analyze the economy. Funds are the agents that are used, but not consumed, in the economic process. They are transformative agents such as labor power, land, and capital. Flows are the elements transformed by the funds (income for example). Building on this framework, Carter and Barrett (2006), showed that while studying poverty, focusing on either flow or fund makes a considerable difference. An individual may be structurally poor because he does not own any "fund" to produce a "flow" of income above poverty line. But he may well be just transient poor since he owns a fund but only failed but the flow production failed temporarily.

Fifth, it does not account for non-trade off cases in poverty. Indeed, the monetary approach assumes trade-offs between the different poverty dimensions. But this is not always the case. For example, increasing consumption does not substitute for a deterioration in health dimension, say losing a child. Hence, Scheidel (2012) argues that the monetary approach is in the realm of "weak sustainability". A "strong sustainability" approach would account for non-trade off cases by building on several types of capital: in health, education, environment...

Finally, another argument against using income and consumption in identifying the poor is that monetary tools are more subject to measurement errors. Measuring consumption and income is more likely to include errors of response (Evans, 2020), than relying on direct measurement of goods or deprivations. 


\section{The Capability Approach:}

a. Origin and Definition

Recalling the works of the field pioneers, one might argue that their approach was not exclusively monetary. Indeed, Booth's study of the east end of London, though mainly concerned with monetary poverty, also documented multidimensional poverty in a sense, because he reported on such metrics as the nature and regularity of employment (Ruggeri Laderchi, 2003). Rowntree (1902) defined a "secondary poverty" category, for those in "obvious want and squalor". These are the ones that fall above the monetary poverty line but still present with what Rowntree saw as direct expressions of poverty he could not ignore.

However, Amartya Sen was the first to introduce a competing framework to conceptualize poverty based on non-monetary measures: the capability approach. He sees development as the bettering of each individuals' capabilities, not as the maximization of utility (Sen, 1985; 1999). At the basis of this approach is the idea of functionings. They are the "doings and beings" that an individual values: being well-nourished or welleducated for example.

Sen argues that functionings are as diverse as our societies. The variability even goes to the level of individuals and he defines the set of all functioning vectors that one individual can achieve as a capability set. Freedom is also at the core of the capability approach, as Sen outlines that an individual may or may not choose a certain functioning or capability set: the difference between a starving person and a fasting person is that one chooses not to eat, while the other has nothing to eat. As such, poverty is defined within 
this framework as a capability deprivation resulting from a lack of one or more functionings. Given the diversity of functionings, the capability approach is adamant on the multidimensionality of wellbeing.

This does not mean that unidimensional measures such as consumption have no place in this framework. Indeed, monetary measurements play a role in this CA as a mean to achieve certain characteristics: money can be used to purchase a certain amount of calories (Lancaster, 1966, 1971). These characteristics may be converted into functionings depending on the intrinsic constitution of the individual (its metabolism, diseases...), socio-economic variables and the environment (different climates). In addition, public goods and non-market goods play an important role as they help individuals achieve a certain level of functioning. (see Figure 1).

How should we measure poverty then? According to the capability approach, we should measure poverty directly in terms of functioning achievements. In other words, we should investigate shortfalls in the realization of minimal needs for different dimensions: the achievement of basic education, access to health etc. 


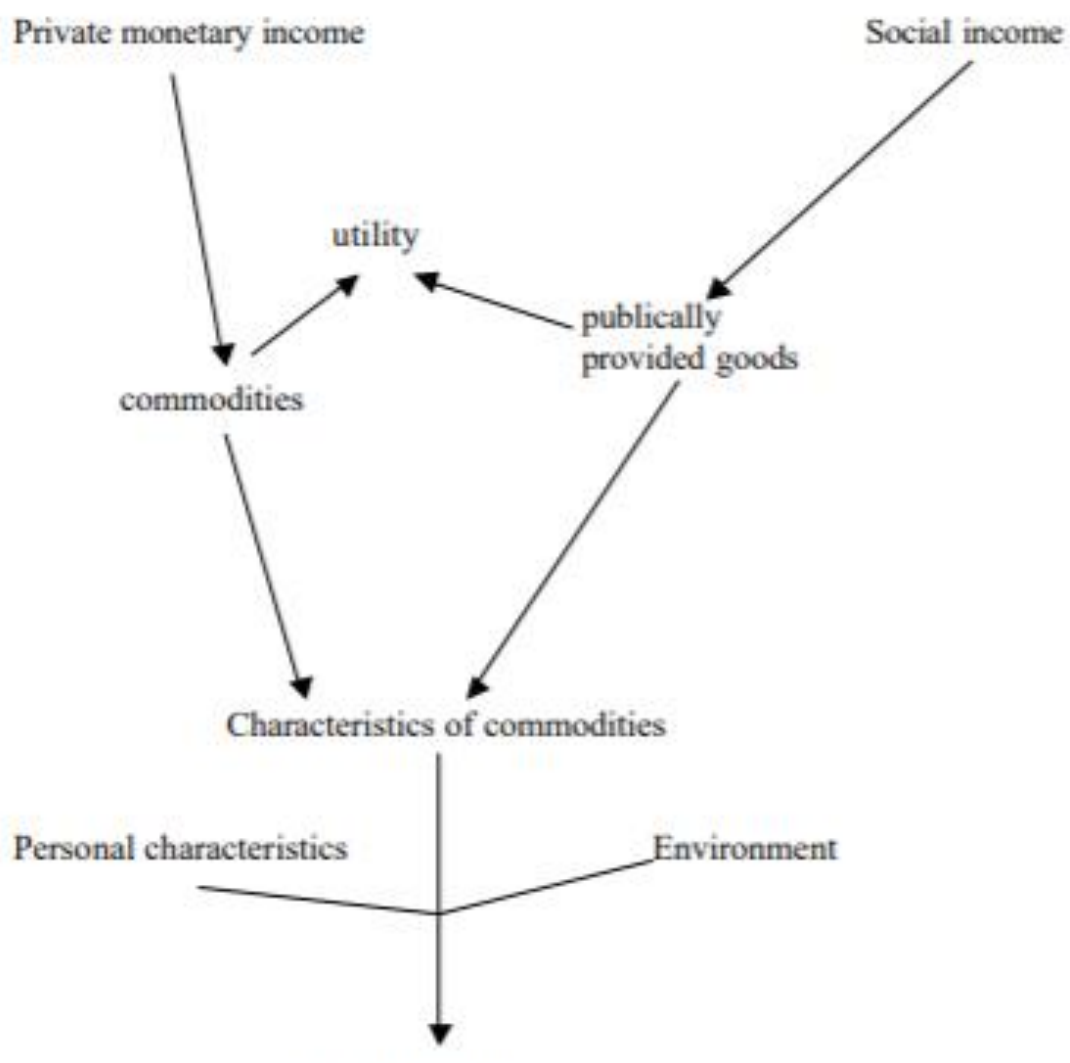

Feasible utilisations

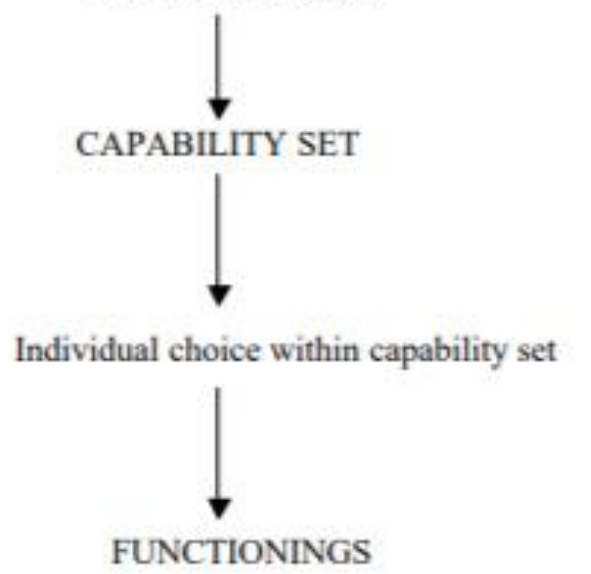

Figure 1 : Capability Approach Links (Ruggeri Laderchi et al., 2003)

\section{b. Advantages}

The Capability approach presents with numerous advantages. 
First, its underlying assumptions are more realistic: it acknowledges market failures and public goods and how they influence wellbeing. For example, a large social welfare program has a considerable influence on individuals well-being and its consequences would be measured in a capability-based poverty assessment. It also holds that individual's preferences are heterogenous (Thorbecke, 2007; Kuklys and Robeyns, 2004) and thus is more flexible than the monetary approach, leaving room from sociodemographic and cultural variability.

Second, it accounts better for the complexity and multidimensionality of poverty (Kakwani and Silber, 2008). As Amartya Sen puts it: "Human lives are battered and diminished in all kinds of different ways, and the first task ... is to acknowledge that deprivations of very different kinds have to be accommodated within a general overarching framework" (2000). Indeed, it is not likely that poverty depends only on monetary measures: Kahneman and Deaton (2010) found that a larger income does not necessarily improve emotional wellbeing. Other non-monetary dimensions play a role, and the capability approach puts them at its core.

Third, it looks directly into outcomes of poverty instead of resource inputs. Resource inputs might be less accurate since they might not be converted into wellbeing functionings due to of externalities or individual's own choices. Thus, it is closer to the real situation of the poor and improves the fit between statistics and reality.

\section{c. Disadvantages}

When researchers try to operationalize the capability approach, a few issues arise. 
First, there is the issue of how to define a universal set of capabilities to be assessed. Indeed, Sen does not provide a list of universally essential capabilities, to leave room for variations across societies. Nussbaum (2000; p74) has tried to define these minimal capabilities, hoping for something that is not "the mere projection of local preferences but it fully international and a basis for cross-cultural attunement". These minimal capabilities include: the right to "Play", "respect for and living with other species" and political "control over one's environment". It may be argued that these are the projection of local western preferences and not universally essential capabilities. However, there seems to be a consensus on at least three dimensions: health, nutrition and education (Dreze and Sen, 1995).

Second, researchers have struggled with measuring capabilities, as potential outcomes that may not have been realized yet (Ruggeri Laderchi et al., 2003). One might argue that if capabilities are basic enough, individuals would not want to pass on them, so measuring capabilities achievements (or functionings) would be synonymous with measuring these. For example, The Multidimensional index of Poverty (Alkire et al., 2015) when considering the education dimension investigates the proportion of individuals in the household that have achieved a certain level of basic education and not the potential of achieving such level. The freedom component that is emphasized in the approach is thus lost: what if the individual chooses to forego basic education on its own accord?

Third, issues of segregation of the poor and aggregation of dimensions arise. Indeed, and as with the monetary approach, the choice of a poverty line might seem arbitrary (Ruggeri Laderchi et al., 2003). In addition, the challenge of aggregation arises because 
of the multidimensionality of poverty according to this framework: how to account for various kinds of poverty in a single index? One can argue for a dashboard style reporting of all deprivations, but aggregation has its advantages as it allows for cross-country comparisons and inform on the severity of poverty.

Last, many critics point out that the capability approach might be very demanding in terms of data and thus inoperative (Sugden, 1993; Comim, 2008). Some scholars continue thus to advocate for monetary measures as proxies for poverty measurement (Meyer and Sullivan; 2003) even though these measures might be lacking in precision given the different conversion factors that lead them to well-being.

\section{The Participatory Approach:}

\section{a. Origin and Definition}

As pointed above, both the monetary approach and the capability approach have been criticized for their "arbitrariness" in defining poverty and poverty cutoffs. This might be to their externality to the poverty phenomenon: the views of the poor themselves on what constitutes poverty are not solicited. This posture is deliberate, as external measurements of poverty are perceived to be more objective (Ruggeri Laderchi, 2003). On the contrary, the participatory approach argues for a deliberately subjective definition and measurement of poverty.

Pioneered by Chambers $(1994,1997)$ this approach was first rolled out in small projects with initial workshops comprising the poor: a subjective definition of poverty would emerge as well as tools to evaluate poverty severity. Poverty is thus equated with a 
shortfall in subjective life satisfaction. This approach was scaled up by the World Bank and by 1998 , half of funded projects included a participatory assessment.

A multitude of tools have been devised to operationalize this approach. These include wealth and well-being ranking, participatory mapping and modelling and seasonal calendars. Assessment tools can be used flexibly according to local context and no rigid methodology is devised (Ruggeri Laderchi, 2003).

In addition, scholars have explored other empirical adaptations of this approach. While previously described poverty assessments tools are based on direct assessments of life satisfaction, Kahneman (2011) choose to measure individuals affect and whether they experience stress or disappointments to draw inferences on the person's subjective state. Chemin (2013) bases its measurements on biological manifestations such as cortisol levels to determine said subjective state.

While non-monetary tools tend to take the center stage in this approach, income or consumption have also been invoked as important poverty dimensions by themselves, as thus used in poverty assessments. For example, Mitra (2014) while devising a multidimensional poverty index for $\mathrm{Nepal}$, adds consumption poverty as a dimension (with $25 \%$ weight) because monetary poverty has emerged as important in a national subjective poverty assessment survey.

\section{b. Advantages}

As explained in the previous section, the poverty approach presents with the main advantage that it is internally based and thus might present with a more realistic 
assessment of poverty. It is also less rigid and draws on variety of assessment tools, devised in collaboration with the poor.

In addition, the use of the participatory approach might be conducive to more cooperation in development projects (Ruggeri Laderchi, 2003): the poor feel empowered and thus adoption rates of policies go up.

\section{c. Disadvantages}

However, this approach is also mined with serious flaws.

First, internal assessment of poverty might be biased. Sen (1999) argues that due to large chronic deprivations, individuals start to adapt their expectations, thus "lowering their gaze". This adaptation leads them to assess in a more positive light objectively terrible living conditions. On the other hand, some well-off individuals, and by the same adaptation mechanism, might "raise their gaze" and produce a negative life assessment (Stewart, 2014). Social conditioning and limited information play a key role here, as well-off people might be isolated from poor people and vice-versa.

Second, while the participatory approach pretends for subjectivity and internality, it is always external observers who conduct the entire process of measurement of poverty. External bias might thus still be present.

Third, da Cuhna (1997) argues that the participatory approach reinforces existing social stratifications and thus might worsen the exclusion of lower castes. Indeed, given that poverty assessment takes places in the context of the community, opposition to current doxa might not be encouraged for fear of retribution. 


\section{III- Methodology}

As we have seen in the previous section, scholars rely on conceptual frameworks to determine which tools to use when identifying poverty. While the monetary approach calls for the use of monetary tools, the capability approach favors non-monetary ones while the participatory approach gives the poor precedence in choosing how to assess their own poverty. These differing frameworks eventually lead to discrepancies in poverty assessments. As mentioned in the introduction, the study of this mismatch has taken many empirical routes, one of which is comparing both monetary and nonmonetary poverty within the same dataset. This paper is concerned with surveying these comparisons with a focus on developing countries, in order to draw generalizations.

To do so, a total of 16 studies focusing on the study of the or between monetary and nonmonetary poverty in developing countries were selected. These studies have used a multitude of indicators and methods to study the mismatch itself. This section will introduce the methodology used to select these studies.

\section{Review process}

Using multiple keywords (“monetary poverty", "multidimensional poverty”, "nonmonetary poverty") we searched databases (Google Scholar, ResearchGate) for studies comparing monetary and non-monetary poverty in developing countries and selected 16 papers covering 14 countries. The flowchart in figure 2 , introduces the process of literature inclusion that led to this result. 


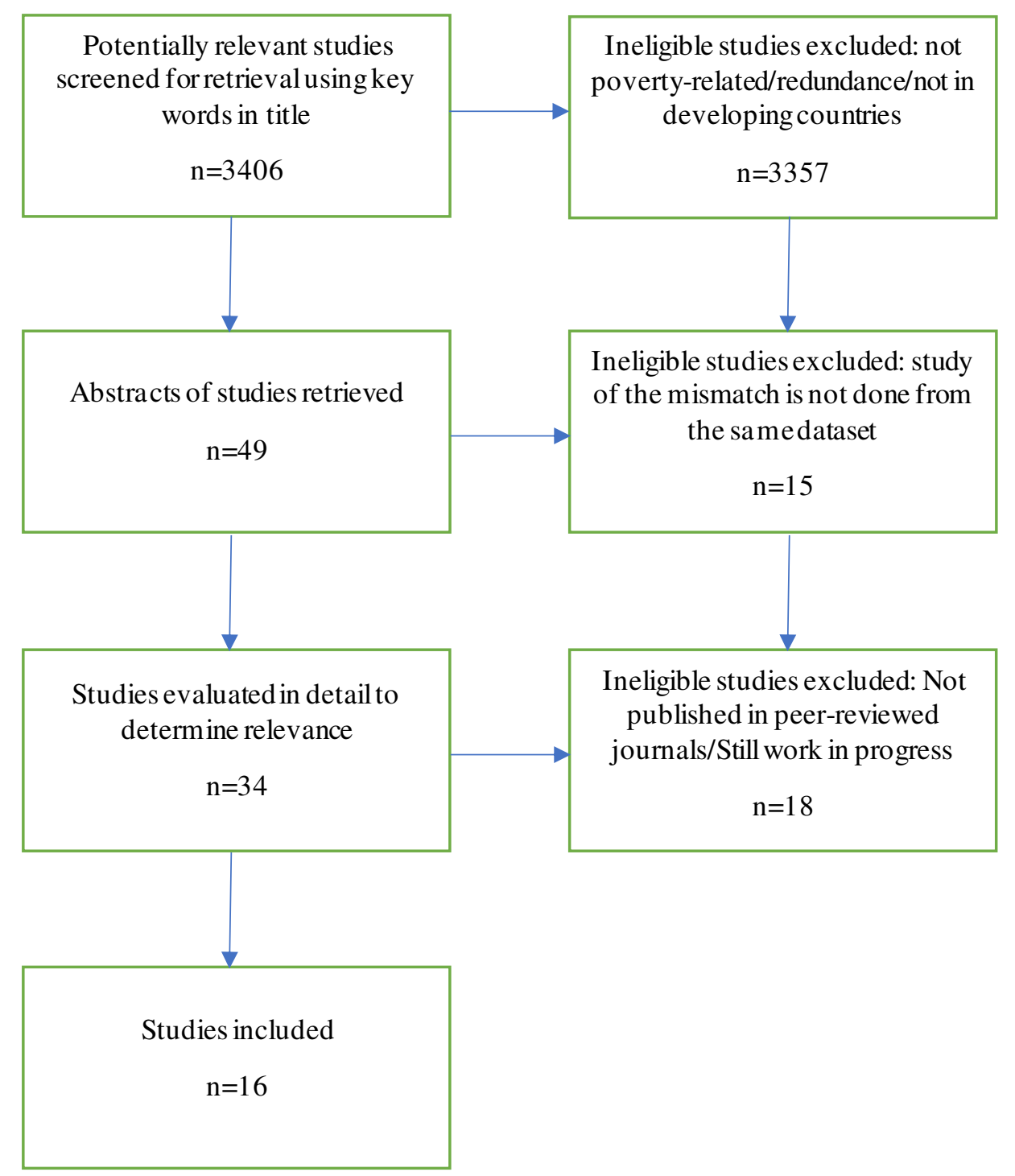

Figure 2: Flowchart for literature inclusion

2. Literature selected:

Amongst developing countries, this literature covers emerging economies (China, India,

South Africa, Brazil, Indonesia) as well as lower-income countries (Nepal, Bolivia,

Rwanda). It covers three main regions in the developing world: Africa, Asia, and Latin

America. The datasets used in this literature vary between cross-sections, time-series, and 
panels, covering a total of 45 time periods: this allows a dynamic analysis of the mismatch between monetary and non-monetary poverty.

Most of these studies (10/16) have used consumption as the monetary indicator. Three have used both income and consumption while only three have used income exclusively. This goes to show the difference in analyzing poverty between developed and developing countries, as more advances economies tend to use income as the main monetary tool to assess poverty with a $60 \%$ relative poverty line (Boarini, 2006). Indeed, given the importance of the informal sector in developing countries, income may not reflect the state of monetary poverty as well as consumption. Following Meyer and Sullivan (2003) we know that an individual may refrain from reporting an illegal source of income, but the effect of that income stream would still appear in his consumption patterns.

With regards to non-monetary indicators, while earlier work tends to focus on single dimensions (Baulch and Masset, 2003) or Principal Component Analysis derived weighted dimensions (Klasen, 2000) most of the selected studies use multidimensional poverty indexes (MPI) based on Alkire-Foster methodology (Alkire and Foster, 2011). Following the Human Development Index, the MPI measures deprivations in the three main consensual poverty dimensions which themselves cover ten indicators: health (child mortality, nutrition), education (years of schooling, child enrolment) and standard of living (electricity, drinking water, sanitation, flooring, cooking fuel and assets). A dual cut-off method is used: within each indicator a household is considered deprived or not given a specific cutoff; then a household is considered poor if deprived in more than a third of all weighted indicators. This methodology presents with numerous advantages as it is decomposable (it is possible to extract which dimension contributes the most to 
poverty) and multidimensional. Besides, it is also adaptable and allows for local variations, in accordance with Sen's original desire to not put forth a set of rigid poverty dimensions. Indeed, besides the global MPI which was described previously, national governments and researchers have tweaked the dimensions and cutoffs according to their own socio-economic context: This is the case in Nepal where Mitra (2014) has chosen to disregard access to drinking water, as this does not constitute a major hindrance in a country rich of freshwater resources. 


\begin{tabular}{|c|c|c|c|c|c|}
\hline $\begin{array}{l}\text { Authors } \\
\text { (Year published) }\end{array}$ & Country & Dataset & Dynamics & $\begin{array}{l}\text { Monetary } \\
\text { tool }\end{array}$ & Non-Monetary tool \\
\hline Kla sen (2000) & South Africa & $\begin{array}{l}\text { SALDRU household } \\
\text { survey (1993) }\end{array}$ & $\begin{array}{l}\text { Cross- } \\
\text { sectional }\end{array}$ & Consumption & $\begin{array}{l}\text { Aggregated } \\
\text { Multidimensional index } \\
\text { with weights } \\
\text { dimensions inferred } \\
\text { through Principal } \\
\text { Component Analysis. } \\
\text { Consumption included } \\
\text { in the index. }\end{array}$ \\
\hline $\begin{array}{l}\text { Baulch } \\
\text { and Masset (2003) }\end{array}$ & Vietnam & $\begin{array}{l}\text { VLSS (1993 and } \\
\text { 1998) }\end{array}$ & Panel & Consumption & $\begin{array}{l}\text { Non-a ggregated Single } \\
\text { Indicators: Level of } \\
\text { Education and } \\
\text { Malnutrition/Children } \\
\text { Stunting }\end{array}$ \\
\hline $\begin{array}{l}\text { Levine } \\
\text { et al. (2012) }\end{array}$ & Uganda & $\begin{array}{l}\text { Uganda DHS (2001 } \\
\text { and 2006) }\end{array}$ & $\begin{array}{l}\text { Time- } \\
\text { series }\end{array}$ & Consumption & $\begin{array}{l}\text { Multidimensional } \\
\text { Poverty Index similar to } \\
\text { OPHI's GlobalMPI }\end{array}$ \\
\hline $\begin{array}{l}\text { Bruck } \\
\text { and Kebede(2013) }\end{array}$ & Ethiopia & $\begin{array}{l}\text { Ethiopian Rural } \\
\text { Household Survey } \\
(1994,2004,2009)\end{array}$ & Panel & Consumption & $\begin{array}{l}\text { Multidimensional } \\
\text { Poverty Index similar to } \\
\text { OPHI's GlobalMPI }\end{array}$ \\
\hline Mitra (2014) & Nepal & $\begin{array}{l}\text { NLSS }(1995,2004, \\
2010)\end{array}$ & $\begin{array}{l}\text { Time- } \\
\text { series }\end{array}$ & Consumption & $\begin{array}{l}\text { Multidimensional } \\
\text { Poverty Index including } \\
\text { Consumption as a } \\
\text { dimension }(25 \%)\end{array}$ \\
\hline $\begin{array}{l}\text { Sumarto } \\
\text { and De Silva (2014) }\end{array}$ & Indonesia & BPS $(2004,2013)$ & $\begin{array}{l}\text { Time- } \\
\text { series }\end{array}$ & Consumption & $\begin{array}{l}\text { Multidimensional } \\
\text { Poverty index similar to } \\
\text { OPHI's GlobalMPI }\end{array}$ \\
\hline Tran et al. (2015) & $\begin{array}{l}\text { Vietnam (3 } \\
\text { provinces only) }\end{array}$ & $\begin{array}{l}\text { "Vulnerability in } \\
\text { Southeast Asia" } \\
\text { Project, } 3 \text { Vietnamese } \\
\text { provinces data (2007, } \\
2008,2010)\end{array}$ & Panel & Consumption & $\begin{array}{l}\text { Multidimensional } \\
\text { Poverty index similar to } \\
\text { OPHI's GlobalMPI }\end{array}$ \\
\hline Wanget al. (2016) & China & $\begin{array}{l}\text { CHNS (China Rural } \\
\text { survey) (2011) }\end{array}$ & $\begin{array}{l}\text { Cross- } \\
\text { sectional }\end{array}$ & Income & $\begin{array}{l}\text { Multidimensional } \\
\text { Poverty index similar to } \\
\text { OPHI's GlobalMPI }\end{array}$ \\
\hline $\begin{array}{l}\text { Seff } \\
\text { and Joliffe(2016) }\end{array}$ & Ethiopia & ESS $(2012,2014)$ & Panel & Consumption & $\begin{array}{l}\text { Multidimensional } \\
\text { Poverty index similar to } \\
\text { OPHI's GlobalMPI }\end{array}$ \\
\hline
\end{tabular}




\begin{tabular}{|c|c|c|c|c|c|}
\hline $\begin{array}{l}\text { Bag } \\
\text { and Seth (2017) }\end{array}$ & $\begin{array}{l}\text { India (3 urban } \\
\text { slums) }\end{array}$ & NSSO $(2005,2012)$ & $\begin{array}{l}\text { Time- } \\
\text { series }\end{array}$ & $\begin{array}{l}\text { Income and } \\
\text { Consumption }\end{array}$ & $\begin{array}{l}\text { Multidimensional } \\
\text { Poverty index similar to } \\
\text { OPHI's GlobalMPI }\end{array}$ \\
\hline Alkire and Shen (2017) & China & $\begin{array}{l}\text { CFPS }(2010,2012, \\
2014)\end{array}$ & $\begin{array}{l}\text { Time- } \\
\text { series }\end{array}$ & $\begin{array}{l}\text { Income and } \\
\text { Consumption }\end{array}$ & $\begin{array}{l}\text { Multidimensional } \\
\text { Poverty index similar to } \\
\text { OPHI's GlobalMPI }\end{array}$ \\
\hline Alkire and Fang (2018) & China & $\begin{array}{l}\text { CHNS (9 waves from } \\
1989 \text { to 2011) }\end{array}$ & Panel & Income & $\begin{array}{l}\text { Multidimensional } \\
\text { Poverty index similar to } \\
\text { OPHI's GlobalMPI }\end{array}$ \\
\hline Das et al. (2021) & India & NSSO $(2005,2012)$ & $\begin{array}{l}\text { Time- } \\
\text { series }\end{array}$ & Consumption & $\begin{array}{l}\text { Multidimensional } \\
\text { Poverty index similar to } \\
\text { OPHI's GlobalMPI }\end{array}$ \\
\hline Gamboaet al. (2020) & $\begin{array}{l}\text { Guatemala } \\
\text { (Q'eqchi indigenous } \\
\text { community) }\end{array}$ & $\begin{array}{l}\text { Primary data (2009- } \\
2011)\end{array}$ & $\begin{array}{l}\text { Time- } \\
\text { series }\end{array}$ & Income & $\begin{array}{l}\text { Single dimensions: } \\
\text { access to land, self- } \\
\text { sufficiency, saturation } \\
\text { of work }\end{array}$ \\
\hline Salecker et al. (2020) & Rwanda & EICV $(2011,2014)$ & $\begin{array}{l}\text { Time- } \\
\text { series }\end{array}$ & Consumption & $\begin{array}{l}\text { Multidimensional } \\
\text { Poverty index similar to } \\
\text { OPHI's GlobalMPI }\end{array}$ \\
\hline Evans et al. (2020) & $\begin{array}{l}\text { Brazil, Bolivia, } \\
\text { Ethiopia, Ecuador, } \\
\text { Ghana and Uganda }\end{array}$ & $\begin{array}{l}\text { Brazil(PNAD, 2015); } \\
\text { Bolivia (EH, 2015); } \\
\text { Ethiopia (ESS, 2015); } \\
\text { Ecuador (ECV, 2014); } \\
\text { Ghana (GLSS, 2013); } \\
\text { Uganda (UNPS, 2015) }\end{array}$ & $\begin{array}{l}\text { Cross- } \\
\text { sectional }\end{array}$ & $\begin{array}{l}\text { Consumption } \\
\text { (African } \\
\text { countries); } \\
\text { Income (Latin } \\
\text { American } \\
\text { countries) }\end{array}$ & $\begin{array}{l}\text { Multidimensional } \\
\text { Poverty index similar to } \\
\text { OPHI's Globa1MPI }\end{array}$ \\
\hline
\end{tabular}

Table 1: Selected empirical literature

IV- Key findings:

The included literature has used different comparison tools to study the differences

between monetary and non-monetary poverty. We will see that while these measures

present with similar trends at first sight, there is a robust mismatch between the 
population identified as poor. This mismatch is even more apparent when considering subgroups and does not improve in a dynamic setting.

\section{Looking at overall trends, both measures seem to move together:}

Amongst the 16 studies included, 13 are either time-series or panel based, which allows to look at overall progression. 12 out of 13 studies find that monetary and non-monetary poverty are moving in the same direction though not at the same rate. Indeed, Salecker (2020) finds that both measures are declining with consumption poverty headcount going from $46 \%$ to $34 \%$ and multidimensional poverty going from $71 \%$ to $45 \%$ between 2011 and 2014. Tran (2015) also finds that both measures are decreasing in Vietnam between 2007 and 2010, though not with the same rate, as monetary poverty is moving faster. In addition, Alkire and Sheng (2017) find that consumption poverty headcount in China drops from $10.7 \%$ to $5.8 \%$ while multidimensional poverty headcount drops from 8.2 to 4\% between 2010 and 2014, thus displaying similar proportions and rates of evolution. Only one study finds different overall trends over time: Bruck and Kebede (2013), analyzing the case of Ethiopia, find similar decreasing trends for two time periods while at the third interval consumption poverty seems to go up, while multidimensional poverty keeps decreasing.

If monetary and non-monetary poverty, analyzed from the same dataset, seem to move in the same direction and sometimes present with similar headcounts, then an argument can be made for using monetary tools only. However, the next sections will show that this similarity rapidly breaks down with a more careful analysis. 
2. However, the crosstabulation of matching headcounts reveals a significant mismatch between monetary and non-monetary poverty:

To delve deeper into the comparison between monetary and non-monetary poverty, most of included literature has resorted to cross-tabulations of headcounts. From these crosstabulations, exclusion and inclusion errors might be extracted. Indeed, there are two ways in which an error in identifying the poor may happen:

- There can be individuals identified as non-monetary poor but not as monetary poor: they are excluded by the prevailing monetary poverty approach and thus might be referred as exclusion error. It is the non-shaded yellow portion of Diagram 1.

- There also might be some individuals identified as poor by income/consumption measures but who do not suffer from non-monetary poverty: they might be referred as inclusion error. It is the non-shaded blue portion of Diagram 1.

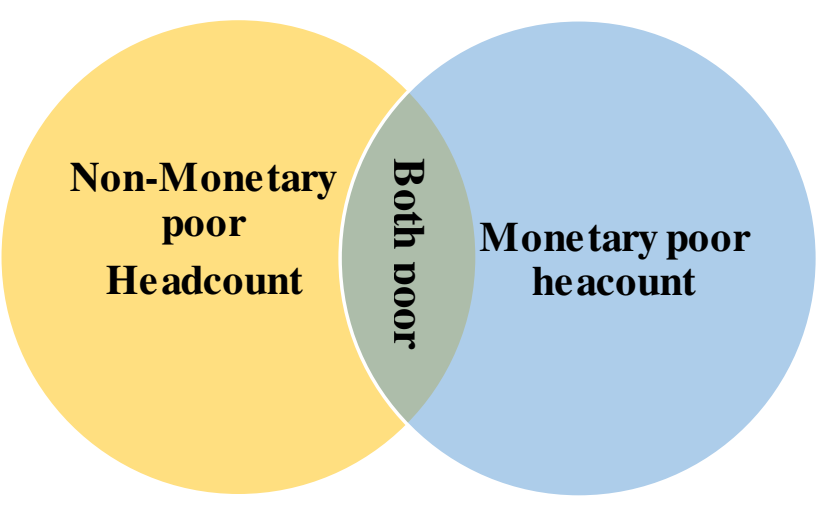

Figure 3: Monetary and non-monetary poverty headcounts representation 
Table 2 reports on exclusion errors found in included literature. When it was available, it also lists inclusion error and "both poor" figures. If the studies are time-series or panels, averages of all time-periods are itemized. It is worth mentioning that each of these studies have used different methodologies and cutoffs, so the results are illustrative only.

Looking at exclusion errors numbers, it appears that every study documents a significant mismatch between monetary and non-monetary poverty. What these numbers mean is that using the monetary approach exclusively would result in disregarding between $8.5 \%$ (Nepal) and $75.4 \%$ (China) of the non-monetary poor. This is the case in Nepal as well (Mitra, 2014) which has an $8 \%$ average exclusion error despite including consumption as a dimension in its multidimensional measure.

In addition, there does not seem to be a clear ordering of countries according to their development level, though we tend to see higher exclusion errors in less developed countries (Ethiopia, Uganda) than in emerging countries (India, Brazil, Indonesia) with the notable exception of China.

It also appears that inclusion error is less important than exclusion error. Taking the example of Uganda, Levine (2012) finds that if only consumption is used a measure for poverty, $44 \%$ of non-monetary poor would be excluded. If we use a multidimensional index of poverty (which does not include consumption or income as a dimension), only $5 \%$ of consumption poor would be disregarded.

One might argue that the mismatch may be resolved with different cutoffs applied to monetary and non-monetary indicators: monetary poverty lines may be too low or nonmonetary poverty lines are too high, which would explain the important exclusion error. 
Indeed, Levine (2012) concedes that the official monetary poverty line in Uganda is probably too low. However, applying a higher monetary poverty line or a lower nonmonetary poverty line still leave us with important exclusion errors and attests to the robustness of this finding. Indeed, Evans (2020) choose to apply a range of different consumption poverty lines, commonly used by academia and development agencies $(1.90 \$ /$ day; $3.3 \$ /$ day and $5.5 \$ /$ day $)$ while also varying the poverty line in the multidimensional index $(\mathrm{k}=1 / 3 ; \mathrm{k}=1 / 4 ; \mathrm{k}=1 / 5)$. Looking at at nine different couplings of monetary and non-monetary poverty lines $(1.90 \$ /$ day and $\mathrm{k}=1 / 3 ; 1.90 \$ /$ day and $\mathrm{k}=1 / 4 \ldots)$ he finds that the exclusion error does vary but is still significant. It varies between $23.1 \%$ and $51 \%$ in Ghana for example.

Another way of emphasizing the mismatch is to directly explore the correlation between monetary and non-monetary poverty. Wang et al. (2014) finds a 0.43 correlation in rural China between both measures, while Salecker (2020) only finds a 0.15 correlation in Rwanda. Mitra (2014), analyzing the case of Nepal finds a 0.4 correlation between both measures, but its multidimensional index includes consumption with a $25 \%$ weight. Klasen (2000) finds a high correlation between both measures in South Africa but signals that this might not be generalizable because of the specific apartheid legacy: government policies propelled favored groups' consumption and non-monetary indicators while black people were ignored for both. Overall, these correlations seem to be weak, especially when considering monetary tools as a reliable proxy for direct measurements of poverty. 


\begin{tabular}{|c|c|c|c|c|}
\hline $\begin{array}{l}\text { Authors } \\
\text { (Year published) }\end{array}$ & Country & Both poor & $\begin{array}{l}\text { Exclusion } \\
\text { Error }\end{array}$ & $\begin{array}{l}\text { Inclusion } \\
\text { Error }\end{array}$ \\
\hline Klasen (2000) & South Africa & & $30 \%$ & \\
\hline $\begin{array}{l}\text { Levine } \\
\text { et al. (2012) }\end{array}$ & Uganda & $20 \%$ & $44 \%$ & $5 \%$ \\
\hline $\begin{array}{l}\text { Bruck } \\
\text { and Kebede(2013) }\end{array}$ & Ethiopia & $37.3 \%$ & $33.6 \%$ & \\
\hline Mitra (2014) & Nepal & & $8.5 \%$ & \\
\hline $\begin{array}{l}\text { Sumarto } \\
\text { and De Silva (2014) }\end{array}$ & Indonesia & $3.7 \%$ & $10.35 \%$ & $7.67 \%$ \\
\hline Tran et al. (2015) & $\begin{array}{l}\text { Vietnam (3 } \\
\text { provinces only) }\end{array}$ & $5.7 \%$ & $34.1 \%$ & \\
\hline Wanget al. (2016) & RuralChina & & $69 \%$ & \\
\hline $\begin{array}{l}\text { Seff } \\
\text { and Joliffe(2016) }\end{array}$ & Ethiopia & $12 \%$ & $34.5 \%$ & \\
\hline Alkire and Shen (2017) & China & $2.4 \%$ & $75.4 \%$ & \\
\hline Das et al. (2020) & India & & $20 \%$ & \\
\hline Salecker et al. (2020) & Rwanda & $30.5 \%$ & $47.5 \%$ & $28.4 \%$ \\
\hline Evans et al. (2020) & Brazil & $1.6 \%$ & $14.9 \%$ & \\
\hline Evans et al. (2020) & Bolivia & $5.8 \%$ & $21.7 \%$ & \\
\hline Evans et al. (2020) & Ethiopia & $61.3 \%$ & $30.3 \%$ & \\
\hline Evans et al. (2020) & Ecuador & $3 \%$ & $16.3 \%$ & \\
\hline Evans et al. (2020) & Ghana & $18.7 \%$ & $37 \%$ & \\
\hline Evans et al. (2020) & Uganda & $34.3 \%$ & $38.8 \%$ & \\
\hline
\end{tabular}

Table 2: Exclusion error in selected empirical literature 


\section{Population Subgroup analysis}

Another way to look at the mismatch between monetary and non-monetary poverty is to look more closely at subgroups of the population. This analysis will help us further our understanding of the differences between both measures and grasp their potential for informing policy. The empirical literature has used different tools to probe the mismatch at the subgroup level, amongst which poverty risk analysis and quintile analysis. The latter focuses on the proportion of non-monetary poor in the monetary quintile distribution, while the former looks at independent variables (household size, ethnicity, space...) and compare their effect on monetary and non-monetary poverty.

\section{a. Quintile analysis}

As mentioned previously, quintile analysis uses monetary quintile distribution, either consumption or income distribution, and matches it with non-monetary poverty status. For each consumption (or income) quintile, a proportion of non-monetary poverty is thus presented, with a focus on the richest monetary quintile.

Table 3 presents results from included literature. When time-series or panel data were used, figures from all time-periods are reported.

For all countries where such analysis was made, non-monetary poverty is present amongst the richest monetary quintile. This phenomenon seems to be even more important for lower income countries: Salecker (2020) finds that amongst Rwanda's monetary richest quintile, nearly half $(48.11 \%)$ are multidimensional poor, while Levine (2012) finds a 30\% figure in Uganda. This proportion does seem to go down with further poverty alleviation: Bruck and Kebede (2013) find that in Ethiopia the proportion of non- 
monetary poor amongst the richest consumption quintile goes down from $74 \%$ to $31 \%$ between 1994 and 2009.

\begin{tabular}{|l|l|c|c|}
\hline \multicolumn{2}{l}{ Authors } \\
Year published)
\end{tabular}

Table 3: Dynamic studies of the mismatch

In addition, while it is expected that the bottom monetary quintile would concentrate nonmonetary poverty, analysis of total non-monetary poverty headcounts proves the opposite. Alkire and Sheng (2017) find that less than half of all non-monetary poor belong to the lowest monetary quintile. Seff (2016) pushed the analysis further in Ethiopia, by comparing both the monetary and non-monetary poverty distribution, finding that $73 \%$ of total population would be placed in a different quintile depending on poverty's definition. Who are these monetary rich, non-monetary poor people? Are they ascetics who choose to forego important functionings? Alkire and Sheng (2017), 
decomposing the multidimensional index for this subgroup, found that it is mainly school attendance and nutrition that contribute to their non-monetary poverty. Thus, two facts are revealed: having enough monetary means does not necessarily translate into enough calories consumed and is not a good predictor of access to a public good (schooling in China). These findings challenge the monetary approach argument for consumption or income being a good proxy to measure direct deprivations.

\section{b. Poverty risk analysis}

Given the apparent mismatch between monetary and non-monetary poverty, it is interesting to look at how each impacts subgroups of the general population. Indeed, a mismatch at the level of general headcounts may reveal deeper disagreements at the subgroup level, with differing poverty risks. To probe this hypothesis, the included literature has tended to use logit regressions with either monetary or non-monetary poverty as a dependent variable, and different population characteristics as independent variables. The range of tested independent variables is large with some related to the composition of the household (household size, sex of the head of the household, age of the head of the household), while others are linked to more general socio-demographic indicators (ethnicity, employment) and geography (Urban or rural, region). In all included literature, this analysis has led to find at least one independent variable for which monetary and non-monetary measures disagree: it is significantly associated with an increase or decrease in one measure while having the opposing effect or no effect on the other measure.

With regards to household composition, one disagreement seems to emerge on the household size. While monetary poverty increases with household size, non-monetary 
poverty is not impacted in the same way. Indeed, Salecker (2020) finds a positive effect of household size on monetary poverty while a negative one on non-monetary poverty in Rwanda: each additional household member increases the risk of monetary poverty by around $7 \%$ while it decreases the risk of multidimensional poverty by $3-4 \%$. In addition, Tran (2015), finds a that while monetary poverty increases with household size in Vietnam, non-monetary poverty has a convex relationship with this independent variable: the risk of non-monetary poverty is only increased for households of 3 to 6 members while it decreases for households of less than 3 or more than 6 members. Bruck and Kebede (2013) analyzing the case of Ethiopia, confirm this disagreement, by finding an important monetary poverty risk with increasing household size, while no significant non-monetary risk is associated with that variable. Reasons for this disagreement might be found in the conceptual frameworks that guide both monetary and non-monetary poverty measurements. Indeed, we have seen that the capability approach leaves room for externalities such as free public interventions, while the monetary approach ignores them. This might be important in countries such as Rwanda and Ethiopia, where education, an important non-monetary dimension, is provided as a public service. In addition, it seems that this disagreement is specific to developing countries: Boarini (2006) and Perry (2002) in their review of the mismatch between monetary and non-monetary poverty in OECD countries do not report the same finding.

Regarding general socio-demographic variables, disagreements between both measures seem to emerge concerning ethnicity and employment.

Indeed, monetary and non-monetary measures do not identify the same ethnic groups as more prone to being in a state of poverty. In Vietnam for example, Tran (2015) finds that 
minority groups suffer more on average from consumption poverty than monetary poverty and posits that this might be to their geographic remoteness and non-inclusion in the monetary economy. In India, Bag and Seth (2017) find that people belonging to indigenous communities without any caste reservation certificates are unfailingly worse off in non-monetary poverty while not being more prone to consumption poverty. In Nepal, Mitra (2015) has found the same for the Muslim community, with consistently high non-monetary poverty risks and average consumption poverty risks. In Apartheid South Africa, Klasen (2000) finds that Africans are disproportionally more deprived in non-monetary dimensions than monetary ones, while finding the reverse for the Colored's community.

With regards to employment status, it seems to have a more important effect on monetary poverty than non-monetary poverty. Indeed, in Rwanda, Salecker (2020) finds that being unemployed increases the risk of monetary poverty by 5 to $7 \%$ (depending on which regression model is used), while there is no significant effect on multidimensional poverty. Alkire and Fang (2018) confirm this finding in China, by showing that compared to any other occupation, being jobless is associated with a higher risk of monetary poverty, which is not the case with non-monetary poverty for which farmers and hunters are worse-off. This finding brings us again to the inherent differences between the monetary and non-monetary approach and the latter's emphasis on non-market goods and services.

At last, looking at geographic variables, a general finding seems to emerge: the regional distribution of monetary and non-monetary poverty is vastly different. Indeed, Klasen (2000) finds that in South Africa, nearly $50 \%$ of the exclusively monetary poor (monetary 
poor only) are concentrated in the Old Provinces while $12 \%$ of exclusively non-monetary poor (non-monetary poor only) live there. The situation is reversed in the African Bantustans with disproportionally more non-monetary poor only and few monetary poor only. In Uganda, Levine (2012) finds that the Northern region holds a disproportionally high share of multidimensionally poor only. Alkire and Fang (2018) also find quite different geographic distributions for monetary and non-monetary poverty in China. In addition, Seff (2016) finds that the SNNP region in Ethiopia presents more consumption poverty only than multidimensional poverty, while the opposite is true for the Oromia region. These differences might point to different development policies at the government level: Mitra (2014) reports that following post-civil war efforts, the Nepalese far western and mid-western regions saw significant improvements in multidimensional poverty with no large decline in monetary poverty.

\section{Taking a dynamic lens, does not improve the mismatch:}

We have now seen how monetary and non-monetary poverty present with a significant mismatch and disagreements on poverty risks. However, these analyses were performed in a static setting and chronicity is an important feature of poverty. Given that monetary measures such as income and consumption are flow variables and thus more prone to volatility than fund variables, it may be argued that the mismatch between both types of poverty would dissolve eventually. The only way to verify this hypothesis is through a panel study following the same individuals for a certain period.

The selected literature includes such panel studies, and a general finding is that the mismatch between monetary and non-monetary poverty is not improved when switching from static to dynamic settings. Indeed, Baulch and Masset (2003), using Chi-square tests 
of independence, find that the distribution of consumption poverty is as different from that of food and education poverty in both dynamic and static setting. Also in Vietnam, Tran (2015) finds that among those who escaped consumption poverty, only $17 \%$ also rose from non-monetary poverty. Considering a representative Chinese panel of 1537 households for 9 time-periods, Alkire and Fang (2018) found that only half of the chronic monetary poor were also chronic non-monetary poor. Looking at Ethiopian panel data, Seff (2016) finds that consumption poverty does not predict multidimensional poverty and vice-versa: $41 \%$ of people whose multidimensional measure worsened saw their consumption poverty improve while $53 \%$ of people whose multidimensional measure improved, saw their consumption poverty worsen.

In addition, our hypothesis that monetary measures present with disproportionally higher volatility compared to non-monetary measures does not seem to hold true. While, nonmonetary poverty does present with slightly more stability, it is also surprisingly dynamic. This is the case in Ethiopia, where Bruck and Kebede find that only $64 \%$ of individuals are chronic non-monetary, a slight increase from the 53\% consumption poor. These surprising dynamics might be due to people relocating, health deterioration or generational change.

Furthermore, monetary and non-monetary measures seem to present with different properties in a dynamic setting, notably with regards to shock predictability. Indeed, Seff (2016) finds that Ethiopian households who fell into non-monetary poverty were $15 \%$ more likely to have experienced a shock between the two waves of panel. This predictive ability is not found in consumption poverty. 


\section{V- Conclusion}

In the previous section, and based on included literature, we have found that although monetary and non-monetary measures may present with similar overall trends, a more careful analysis reveals an important mismatch between populations identified as suffering from poverty. Moving to subgroup analysis, this mismatch is clearer, with nonmonetary poverty present amongst the richest monetary quintile, and important disagreements on poverty risks between both measures: being poor in one measure is associated with different independent variables than for the other measure. Changing our gear to a dynamic setting, we find that the mismatch issue is not resolved, and the theory of convergence over time does not hold.

What policy implications can be drawn from these findings?

First, if we hold that non-monetary measures present with a more direct profile of poverty, it is difficult to accept monetary measures as a valid proxy. Indeed, it would clearly have a detrimental effect on targeting with sizeable exclusion errors for the nonmonetary poor but monetary non poor. It would also allow for a sizeable inclusion error for the monetary poor but not non-monetary poor. These mistargeting errors can be high with up to $75.4 \%$ exclusion error in China (Alkire and Sheng, 2017) leading to misdistribution of resources: $30 \%$ of multidimensional poor not receiving any government subsidy (Alkire and Sheng, 2017). Furthermore, using monetary measures only might prove problematic to assess government policies, since they do not necessarily account for publicly provided goods such as health and education. Indeed, Mitra (2014) finds that in Nepal, using consumption only as a proxy for poverty would 
not have acknowledged important improvements for non-monetary dimensions in the mid-western and far western regions: these regions had benefited from important poverty alleviations policies post-civil war. In addition, why should we accept a proxy if we can construct a more direct measure of poverty from the same dataset? Indeed, all included literature has managed to produce both monetary and non-monetary measures from the same survey data.

Second, if we accept income or consumption as poverty dimensions in their own right, we must acknowledge their inherent differences with non-monetary measures. Indeed, as they present with different poverty risks and identify different populations as poor, we should be clear that the two measures reveal distinct kinds of poverty. Targeted policies for each type of poverty should thus follow: the monetary poor would benefit from cash transfer policies, while the non-monetary poor would be keener on structural long-term change pertaining to their health and education situation.

Finally, it should be noted that the study of the mismatch in a dynamic setting has only been carried out in a few studies given the scarcity of panel data. Further research is needed to assess how the two measures differ in the long-term and how they react to targeted policies. Until then, it would be safer to use both measures concomitantly in all policy formulation and assessment, without one taking precedence over the other, to get a complete picture of the poverty phenomenon. 


\section{References:}

Alkire, S. (2018). 'The research agenda on multidimensional poverty measurement: important and as-yet unanswered questions', OPHI Working Paper 119, University of Ox ford.

Alkire, S. and Fang, Y.(2018). 'Dynamics of multidimensional poverty a nd uni-dimensional income poverty: an evidence of stability a nalysis from China', Social Indicators Research, published online 03 April 2018. Available here.

Alkire, S. and Foster, J. (2011). ‘Counting a nd multidimensional poverty measurement', Journal of Public Economics, vol.95(7-8),pp.476-487

Alkire, S., Conconi, A., Robles, G., \& Seth, S. (2015). “Multidimensional poverty index.”MPI Methodological Note, University of Oxford

Alkire, S. and Robson, M. (2018). 'On data a vailability for assessing monetary and multidimensional poverty', OPHI Research in Progress 52a, University of Oxford.

Alkire, S., and Santos, M. (2014). "Measuring a cute poverty in the developing world: Robustness and scope of the multidimensional poverty index", World Development, 59:251.

Alkire, S., Foster, J., Seth, S., Roche, J. M., \& Ballon, P. (2015). Multidimensional poverty measurement and analysis. Oxford: Oxford University Press

Alkire, Sabina, \& Foster, James. 2011b. Understandings and Misunderstandings of Multidimensional Poverty Measurement. Journal of Economic Inequality, 9(2), 289-314.

Atkinson, A. B. (1989). Poverty and Social Security. London, Harvester Wheatsheaf

Atkinson, A.B. (2019). Measuring Poverty around the World, Princeton, NJ: Princeton University Press.

Bag, S. and Seth, S. (2018). 'Does it matter how we a ssess standard of living? Evidence from Indian slums comparing monetary and multidimensional a pproaches', Social Indicators Research, vol. 140(2), pp. 715 754.

Banerjee, A. V., \& Dufo, E. (2011). Poor economics: A radical rethinking of the way to fght global poverty. U.S.: Public Afairs

Banerjee, Abhijit V., and Esther Duflo. "The Economic Lives of the Poor." The Journal of Economic Perspectives: a Journal of the American Economic Association 21, no. 1 (2007): 141.

Baulch, B., \& Masset, E. (2003). Do monetary and nonmonetary indicators tell the same story about chronic poverty? A study of Vietnam in the 1990s. World Development, 31(3), 441-453.

Boarini, R. \& Mira d'Ercole, M. (2006). Measures of Material Deprivation in OECDCountries," OECD Socia l, Employment and Migra tion Working Papers 37, OECD Publishing.

Bourguignon, F., Benassy-Quere, A., Dercon, S., Esta che, A., Gunning, J., Kanbur, R., Kla sen, S., Maxwell, S., Platteau, J., Spa daro, A. (2010). "Chapter 2: The Millennium Development Goals, an assessment”, In R. Ka bur and M. Spence (eds.), Equity and Growth in a Globalizing World, World Bank: Wa shington, DC. doi: 10.1596/978-0-8213-8180-9.

Bradshaw, J. and Finch, N. (2003). 'Overlaps in dimensions of poverty', Journal of Social Policy, vol. 32(4), pp. 513-525. 
Bruck, T., and Kebede, S. (2013). Dynamics and Drivers of Consumption and Multidimensional Poverty, Berlin: German Institute of Economic Research.

Carter, M.R., Barrett, C.B., 2006. Theeconomics of poverty traps and persistent poverty: a n a sset-based approach. Journal of Development Studies 42, 178-199.

Chambers, R. (1994). "The origins and practice of PRA." World Development22(7).

Cha mbers, R. (1997). Whose Reality Counts? Putting the First La st. London, Intermediate Technology Publications.

Chemin, M. de Laat, J. and Haushofer J. (2013). "Nega tive Rainfall Shocks Increases the Level of Stress Among Poor Farmers in Kenya" Mimeo. Available at http://www.princeton.edu/ joha/publications/Chemin_et_al_2013.pdf .

Clark, D., Hulme, D. (2005). Towards A Unifed Framework for Understanding the Depth, Breadth and Duration of Poverty.

Comim, F. (2008). Measuring Capabilities. . Pages 157-200 of: Comim, Fla vio, Qizilba sh,Mozaffar, \& Alkire, Sabina (eds), The Capability Approach:Concepts, Measures and Applications. Cambridge: Cambridge University Press.

da Cunha, P. V. and M. V. Junho Pena (1997). The limits and merits of participation. Washington DC, World Bank.

Das, P., Paria, B. \& Firda ush, S. (2021). Juxtaposing Consumption Poverty and Multidimensional Poverty: A Study in Indian Context. Soc Indic Res 153, 469-501

Dreze, J. and A. K. Sen (1995). India: Economic Development and Social Opportunity. Delhi, India, Oxford University Press.

Drèze, J., and Sen, A. K. (2013). An Uncertain Glory: India and its Contradictions. Princeton, New Jersey: Princeton University Press

Evans, M. Nogales, R. and Robson, M. (2020). 'Monetary and multidimensional poverty: Correlations, mismatches, and joint distributions', OPHI Working Pa per 133, University of Oxford.

Gamboa, G., Mingorría, S. and Scheidel, A. (2020). 'The meaning of poverty matters: Tradeoffs in poverty reduction programmes', Ecological Economics, vol. 169, p. 106450.

Georgescu-Roegen, N., 1971. The Entropy Law and the Economic Process. Harvard University Press, Cambridge, London.

Geske, D. (2011). "The PRSP Approach and the Illusion of Improved Aid Effectiveness: Lessons from Bolivia, Honduras and Nicaragua". Development Policy Review. 1. 29: 111-133.

Haughton, J., Khandker, S. R. (2009). Handbook on Poverty and Inequality

Johannsen, J.,Zeller, M., Kla sen, S. (2007). The ca pability dilemma in operational poverty a ssessment. Ibero-America Institute Discussion Papers. Vol. 159.

Kahneman, D. (2011). Thinking, Fa st and Slow. Farrar, Straus, and Giroux

Kahneman, D., \& Deaton, A. (2010). High income improves evaluation of life but notemotional wellbeing. Proceedings of the National Academy of Sciences, 107(38), 16489-16493.

Kakwani, N., \& Silber, J. (2008). Many dimensions of poverty. Berlin: Springer.

Kla sen, S. (2000). Measuring poverty and deprivation in South Africa. Review of Income and Wealth, $46(1), 33-58$. 
Konkel, R. (2014). The monetization of global poverty: the concept of poverty in World Bank history, 1944-90. Journal of Global History, 9, pp 276-300 doi: 10.1017/S1740022814000072

Kuklys, W., Robeyns, I. (2004). Sen's capability approach to welfare economics.

Lancaster, K. (1966). A New Approach to Consumer Theory. Journal of PoliticalEconomy, 74(April), $132-157$.

Lancaster, K. (1971). Consumer Demand: A New Approach. Columbia studies in economics, vol. 5. New York: Columbia University Press.

Levine, S., Muwonge, J., Batana, Y. M. (2012). A Robust multidimensional poverty profile for Uganda. Oxford poverty and human development initiative.

Martinez-Alier, J., Munda, G., O'Neill, J., 1998. Weak comparability of values as a foundation for ecologicaleconomics. EcologicalEconomics 26, 277-286

Meyer, B. D., \& Sullivan, J. X. (2003). Measuring the Well-Being of the Poor Using Income and Consumption. Journal of Human Resources, 38(Supplement), 1180-1220.

Mitra, S. (2014). Synergies among monetary, multidimensional and subjective poverty: evidence from NepalSocialIndicators Research, 125(1), 103-125.

Mullainathan, S., Shafr, E. (2013). Scarcity: Why having too little means so much. Macmillan.

Nussbaum, M. (2000). Women and Human Development: A Study in Human Capabilities. Cambridge, Cambridge University Press.

Perry, B. (2002). The mismatch between Income measures and direct outcome measures of poverty, social policy journal of NewZealand, 19, 101-127.

Ravallion, Martin. 2011. On Multidimensional Indices of Poverty. Journal of Economic Inequality, 9(2), 235-248.

Rowntree, B. S. (1902). Poverty. A Study of Town Life. London, MacMilla n and Co

Ruggeri La derchi, C., \& SaithStewart, R.F. (2003). Does it matter that we do not a gree on the defnition of poverty? A comparison of four approaches. Oxford Development Studies, 31(3), 243-274

Sa lecker, L., Ahmadov, A. K., \& Karimli, L. (2020). Contrasting monetary and multidimensional poverty mea sures in a low-income Sub-Saharan African Country. Social Indicators Research.

Scheidel, A., 2013. Flows, funds and the complexity of deprivation: using concepts from ecological economics for the study of poverty. Ecol. Econ. 86, 28-36.

Seers, D. (1969) 'The meaning of development', InternationalDevelopment Review 11(4): 2-6

Seff, I., Jolliffe, D. (2016). Multidimensional Poverty Dynamics in Ethiopia : how do they differ from consumption-based poverty dynamics?Ethiopian Journal of Economics

Sen, A. K. (1985). Commodities and Capabilities. 12. edn. New Delhi: North Holla nd Publ.

Sen, A. K. (1992). Inequality Reexamined. 3. edn. Russell Sage Foundation book. New York: Russell Sage Foundation.

Sen, A. K. (1993). Markets and Freedoms: Achievements and Limitations of the Market Mechanism in Promoting Individual Freedoms. Oxford Economics Papers, 45, 519-541.

Sen, A. K. (1999). Development as Freedom. Oxford: Oxford University Press.

Sen, A. K. (2000). 'A Deca de of Human Development', Journal of Human Development and Capabilities, $1(1)$ 
Spicker, P. (2007). Defnitions of poverty: Twelve clusters of meaning. In P. Spicker, S. A. Leguiza mon, \& D. Gordon (Eds.), Poverty: An international glossary pp. 229-43, London: Zed Books.

Stewart, F. (2014). "Aga inst Happiness: A Critical Appraisal of the Use of Measures of Happiness for Eva luating Progress in Development." Journal of Human Development and Capabilities. Online first.

Sugden, R. (1993) Welfare, Resources and Capabilities: A Review of Inequality Reexamined by Amartya Sen. Journal of Economic Literature, 31, 1947-1962.

Sumarto, S., \& De Silva, I. (2014). Beyond the headcount: Examining the dynamics and patterns of multidimensional poverty in Indonesia. TNP2K Working Paper No. 21 -2014.

Sumner, A. (2007) 'Meaning versus measurement: why do 'economic' indicators of poverty still predominate?', Development in Practice, 17: 1,4-13

Suppa, N. (2016). Comparing Monetary and Multidimensional Poverty in Germany. OPHI Working Papers 103.

Thorbecke, E. (2007). Multidimensional poverty: conceptual and measurement issues. The Many

Dimensions of Poverty (pp.3-19). London: Palgrave Macmillan

Tran V.Q, Alkire S. and Klasen S. (2015). Static and Dynamic Disparities between Monetary and

Multidimensional Poverty Measurement:Evidence from Vietnam In Measurement of Poverty, Deprivation, and Economic Mobility.

UN (2008) United Nations Millennium Development Goals. [online] Available at:

<https://www.un.org/millenniumgoals/bkgd.shtml>

UN (2019) Sustainable Development Goals Report 2019

Wang, X., Feng, H., Xia, Q., and Alkire, S. (2016). “On the relationship between Income Poverty and Multidimensional Poverty in China.” OPHI Working Paper 101, University of Oxford.

Whelan, C. T., Layte, R., \& Maitre, B. (2004). Understanding the mismatch between income poverty and deprivation: Adynamics comparative analy sis. European Sociological Review, 29(4), 287302.

doi:10.1093/esr/jch029

White, Howard (2002) 'Combining quantitative and qualitative a pproaches in poverty analysis', World Development 30(3): 511-22

World Bank (2020) Poverty Overview. [online] Available at: <https://www.worldbank.org/en/topic/poverty/overview\#: :text=The\%20global\%20xtreme\%20poverty\% 20rate,less\%20than\%20\%241.90\%20a\%20day.> [Accessed 23 January 2021]. 